Polish Journal of Ecology

Pol. J. Ecol. (2014) 62: 289-306

Regular research paper

Kinga KOSTRAKIEWICZ-GIERAŁT

Department of Plant Ecology, Institute of Botany, Jagiellonian University, Lubicz str. 46, 31-512

Kraków, Poland, e-mail: kinga.kostrakiewicz@uj.edu.pl

\title{
THE EFFECT OF NEIGHBOURING PLANT HEIGHT, DISTURBANCE LEVEL AND GAP SIZE ON SPONTANEOUS RECRUITMENT OF LARGE-SEEDED AND SMALL-SEEDED SPECIES IN MOLINIETUM CAERULEAE MEADOWS
}

\begin{abstract}
The seed size is considered as a key feature, which effects both: colonizing and competitive abilities of species. The disturbance dependent small-seeded taxa are regarded as superior colonists, whereas the large-seeded taxa are considered as best competitors able to survive the competition from adjacent plants and negative effect of litter. The impact of character of standing vegetation, disturbance level and size of gaps on spontaneous recruitment of seedlings of selected light-seeded species (Gentiana pneumonanthe L., Dianthus superbus L.) and heavy-seeded taxa (Serratula tinctoria L., Gladiolus imbricatus L.) were conducted. The investigations were carried out in two areas (A and B). Both of them were consisted of three adjacent patches of Molinietum caeruleae: dominated by small meadow species (labeled $\mathrm{MC}$ ), prevailed by large-tussocks grasses (labeled GR), and overgrown by willows (labeled SA). In the year 2007, in all patches, ten permanent experimental plots were randomly arranged. In Area A, plots were divided in four square-shaped, neighboring subplots subjected to: no treatment; the removal of litter and moss layers; the removal of litter, bryophytes, and above-ground parts of plants; the removal of litter, moss and the plants, as well as top soil stripping. In the Area B, plots were divided into four
\end{abstract}

subplots measuring from $0.16 \mathrm{~m}^{2}$ to $0.01 \mathrm{~m}^{2}$. In each of them the litter and above-ground part of plant biomass were clipped and removed. The recruitment of seedlings was monitored from 2007 through 2010. In both studied areas, regardless of seed mass, the greatest abundance of seedlings were found in patches $\mathrm{MC}$, and decreased gradually in sites GR and SA. Irrespective of seed size, in subplots where plant cover and litter stayed intact no new genets was noted, moderate appearance of seedlings was observed in subplots without plant necromass, whereas the greatest number of generative progeny was found in subplots without necromass and aboveground parts of plants. The lower abundance of seedlings in subplots without litter, plants and topsoil might have been caused by depletion of seed bank reserves. Moreover, in all patches the number of seedlings of small- and large-seeded taxa increased significantly with augmentation of gap size.

In light of performed studies it might be concluded, that the disturbances might play very important role in active protection of studied taxa. The positive impact of disruption diminishes with increasing of plant canopy height. The removal of plant cover and litter contributes to the greatest seedling recruitment but its beneficial effect diminishes with decreasing of opening size. 
KEY WORDS: abandoned meadow, active protection, Dianthus superbus, Gentiana pneumonanthe, Gladiololus imbricatus, natural recruitment, seed mass, Serratula tinctoria

\section{INTRODUCTION}

Seed mass is an essential trait, which occupies a pivotal position in regeneration strategy of species. The studies conducted in wide spectrum of habitats from old-fields (McConnaughay and Bazzaz 1987, Reader 1993), through pastures (Eriksson and Eriksson 1997) and grasslands (Ryser 1993, Burke and Grime 1996, Eriksson and Jakobsson 1998, Jakobsson and Eriksson 2000, Leishman 2001, Turnbull et al. 2004), to forests (van Ulft 2004) have documented that seed mass affects both colonizing and competitive abilities of species. The aforementioned investigations brought evidence, that the light-seeded taxa are superior colonists in result of substantial diaspore production and fast growth of seedlings. However, due to substantial requirements for the light availability, their recruitment in closed habitats strongly depends on disturbances in continuous plant canopy and necromass. In contrary, the large seeds contain high amounts of nutrient storage tissues, which enable the survivability under the several environmental hazards such as shading, defoliation, as well as nutrient deprivation. In result, the heavyseeded taxa are considered as best competitors able to recruit offsprings in crowded habitats with high litter accumulation.

The review of voluminous international literature on the role of seed mass in recruitment processes showed, that the majority of findings is based on experiments involving seed supplementation (i.e. Moles and Westoby 2004,2006 ), whereas the investigations of spontaneous establishment of offsprings are not numerous (Kern et al. 2013). Particularly needed are studies conducted in populations of the rare species, because they provide valuable data for successful protection programs. Given the unsatisfactory state of knowledge the present studies were undertaken to investigate the natural recruitment in populations of selected endangered small- and large-seeded species occurring in Molinietum caeruleae meadows with different habitat conditions. The detailed goals focused on assessment of: (1) the impact of height of neighboring vegetation on seedling abundance, (2) the influence of disturbance level on appearance of seedlings, (3) the effect of gap size on emergence of seedlings.

I hypothesize that: (1) the number of seedlings of each species decreases with augmentation of height of standing vegetation, (2) the abundance of seedlings of small- and large-seeded species increases with growing disturbance level, (3) large-seeded species colonize small gaps, while small-seeded taxa appear in large openings.

\section{STUDY SPECIES}

Four species typical for wet meadows of the Molinion alliance (Matuszkiewicz 2012), occurring in Atlantic, Central and Eastern Europe, as well as northern and western Asia (Meusel et al. 1965) and belonging to plants threatened in entire Europe (APPENDIX I), have been chosen for investigation. All of selected taxa represent perennial herbs, which create inflorescences consisting of several insect-pollinated flowers and produce numerous self-sowing or wind-dispersed seeds. The main character differing selected taxa is seed mass. Kahmen and Poshold (2008a) divide seeds into two categories: small, with mass $<0.5 \mathrm{mg}$, and large, $0.5-2.0 \mathrm{mg}$. In the present study, the small-seeded species are represented by Gentiana pneumonanthe L., with seeds weighing $0.05 \mathrm{mg}$ (Simmonds 1946) and Dianthus superbus $\mathrm{L}$., with seeds reaching $0.07 \mathrm{mg}(\mathrm{Bu}$ et al. 2007). The large-seeded taxa are represented by Serratula tinctoria L., with seeds attaining $1.74 \mathrm{mg}$ (Cerabolini et al. 2003) and Gladiolus imbricatus L., with seeds achieving $1.8 \mathrm{mg}$ (Kubikova and Zeidler 2011).

\section{STUDY AREA}

The studies were carried out in Kostrze district localized on western edge of Krakow, south of the Vistula River (southern Poland). The research area is located at $c a 210 \mathrm{~m}$ a.s.l, on a low flood terrace of the Vistula, 3.0-6.0 $\mathrm{m}$ high. Most of it is covered by unmanaged Molinietum caeruleae patches characterized by presence of Dianthus superbus, Gentiana 
pneumonanthe, Gladiolus imbricatus and Serratula tinctoria (Dubiel 1991, 1996 and personal observations). The studies were carried out in two areas (A and $\mathrm{B})$. In both of them, three adjacent, abandoned Molinietum caeruleae patches with different species composition and habitat conditions were selected (APPENDIX II). The patches labeled MC were dominated by meadow species, creating delicate, creeping stems or small-tussocks. The small species intercepted very low amount of irradiance, contributing to strong insolation of the plot. The places labeled GR were prevailed by the large-tussock grasses, with tall-growing stems and closely packed leaves, strongly prevented the penetration of sunlight on the surface of the ground. The sites named SA were overgrown by willows, with wide leaves and densely distributed stems, which shaded the whole patch.

\section{MATERIAL AND METODS}

In the year 2007, in each of above described patches ten permanent experimental plots were randomly arranged. They were established at least 2.0 meters from the border of patch to avoid edge effect. The experimental design is given by KostrakiewiczGierałt (2012).

In Area A plots were divided into four, square-shaped, adjacent subplots measuring $0.09 \mathrm{~m}^{2}$. The subplots were subjected:

- no treatment (subplot 1),

- low disturbance level i.e. the removal of litter and moss layers (subplot 2),

- medium disturbance level i.e. the removal of litter, bryophytes, and above-ground parts of plants (subplot 3),

- high disturbance level i.e. the removal of litter, moss and the plants, as well as top soil stripping to the depth 3-5 cm (subplot 4).

In the Area $\mathrm{B}$ plots were divided into four, square shaped, neighboring subplots, reaching with the area of $0.16 \mathrm{~m}^{2}$ (subplot I), $0.09 \mathrm{~m}^{2}$ (subplot II), $0.04 \mathrm{~m}^{2}$ (subplot III), and $0.01 \mathrm{~m}^{2}$ (subplot IV). In each of them the litter and the above-ground part of biomass were clipped and removed. The establishment of generative descendants was monitored once a week in May, June, July and August, and once every two weeks in April, September and October, from year 2007 to year 2010. The effect of adjacent plant height, disturbance level and gap size on recruitment process was characterized by absolute, cumulative number of seedlings calculated by adding seedlings that appeared in particular plots (subplots) over the course of four years.

The statistical analysis were based on the nonparametric Kruskal-Wallis test, which was applied to examine whether there were significant differences in:

- the mean number of seedlings that appeared in permanent plots among patches in both areas;

- the mean number of seedlings that appeared in different treatment (size) subplots within each patch.

\section{RESULTS}

\subsection{The impact of neighbouring plant height on seedling abundance}

The greatest abundance of both smalland large-seeded species seedlings were found in patches MC, while it decreased gradually in sites GR and SA (Table 1). The number of seedlings of small-seeded species in places MC achieved from 11.1 to 21.1, in sites GR it ranged from 7.5 to 15.3 , while in places SA it reached from 6.2 to 10.5 . The abundance of seedlings of large-seeded taxa in sites MC achieved from 11.2 to 58.9 , in patches GR it amounted from 9.2 to 21.0 , whereas in places SA it ranged from 8.6 to 18.1. The statistical significance of differences in number of seedlings of each species noted in successive patches is shown in Table 2.

\subsection{The influence of disturbance level on appearance of genets}

In subplots, where plant cover and litter stayed intact (I) new genets were not noted, moderate appearance of generative offsprings was observed in subplots without necromass (II), whereas the greatest number of descendants was found in subplots without necromass and aboveground parts of plants (III). The lower seedling abundance was observed in subplots without litter, plants and topsoil (IV).

The detailed recruitment rates of the small-seeded species are given in Table 3 . The 
Table 1. The recruitment of seedlings of Gentiana pneumonanthe, Dianthus superbus, Serratula tinctoria and Gladiolus imbricatus recruited during whole study period in in experimental plots within established within patches of Molinietum caeruleae dominated by low meadow species (MC), large-tussock grasses (GR) and willows (SA) in Area A and Area B.

\begin{tabular}{|c|c|c|c|}
\hline Species & Area & Patch & $\begin{array}{l}\text { The average number of seedlings } \\
( \pm S D)\end{array}$ \\
\hline \multirow{6}{*}{ Gentiana pneumonanthe } & \multirow{3}{*}{ A } & $\mathrm{MC}$ & $11.1(4.3)$ \\
\hline & & GR & $7.5(5.0)$ \\
\hline & & SA & $6.7(3.6)$ \\
\hline & \multirow{3}{*}{ B } & $\mathrm{MC}$ & $13.2(4.5)$ \\
\hline & & GR & $9.4(5.7)$ \\
\hline & & SA & $8.0(5.0)$ \\
\hline \multirow{6}{*}{ Dianthus superbus } & \multirow{3}{*}{ A } & $\mathrm{MC}$ & $11.5(4.9)$ \\
\hline & & GR & $9.7(8.7)$ \\
\hline & & SA & $6.2(4.8)$ \\
\hline & \multirow{3}{*}{ B } & $\mathrm{MC}$ & $21.1(2.6)$ \\
\hline & & GR & $15.3(2.1)$ \\
\hline & & SA & $10.5(3.3)$ \\
\hline \multirow{6}{*}{ Serratula tinctoria } & \multirow{3}{*}{ A } & $\mathrm{MC}$ & $25.6(7.6)$ \\
\hline & & GR & $21.0(9.2)$ \\
\hline & & SA & $18.1(14.0)$ \\
\hline & \multirow{3}{*}{ B } & MC & $58.9(10.1)$ \\
\hline & & GR & $31.8(7.4)$ \\
\hline & & SA & $18.7(10.0)$ \\
\hline \multirow{6}{*}{ Gladiolus imbricatus } & \multirow{3}{*}{ A } & $\mathrm{MC}$ & $11.2(1.8)$ \\
\hline & & GR & $9.1(3.7)$ \\
\hline & & SA & $8.6(5.6)$ \\
\hline & \multirow{3}{*}{ B } & MC & $19.9(5.3)$ \\
\hline & & GR & $15.7(6.9)$ \\
\hline & & SA & $10.9(5.0)$ \\
\hline
\end{tabular}

average number of Gentiana pneumonanthe seedlings ranged from 0.3 to 2.3 in subplots II, from 3.0 to 5.9 in subplots III, and from 2.4 to 4.9 in subplots IV. The mean number of descendants of Dianthus superbus reached from 0.2 to 2.8 in subplots II, from 3.8 to 5.4 in subplots III, and from 1.2 to 5.0 in subplots IV. The statistical significance of differences of seedling recruitment in particular subplots is given in Table 4 .

The data of establishment of the largeseeded taxa are given in Table 5 . The mean number of seedlings of Serratula tinctoria attained from 1.0 to 3.8 in subplots II, from 11.8 to 18.2 in subplots III, and from 2.5 to 6.4 in subplots IV. The mean number of seedlings of Gladiolus imbricatus reached from 1.0 to 1.2 in subplots II, from 4.0 to 7.4 in subplots III, and from 2.6 to 3.9 in subplots IV. The statistical significance of differences in seedling recruitment in particular subplots is given in Table 6.
5.3. The effect of gap size on emergence of generative progeny

Irrespective of patch character the number of seedlings of all taxa diminished gradually from the largest subplots (I), via intermediate openings (II and III), to the smallest ones (IV). The number of seedlings of the small-seeded species in particular subplots is shown in Table 7. The average abundance of generative offsprings of Gentiana pneumonanthe reached from 2.6 to 6.3 in the largest gaps, from 1.5 to 3.5 in the intermediate openings and from 1.1 to 1.4 in the smallest ones. The mean number of Dianthus superbus individuals achieved from 3.8 to 7.5 in the greatest gaps, from 2.3 to 5.3 in the medium openings and from 1.5 to 3.5 in the smallest ones. The statistical significance of differences in seedling recruitment in consecutive subplots is given in Table 8 .

Also the abundance of descendants of the large-seeded taxa raised gradually with aug- 
mentation of opening area (Table 9). The average recruitment rates of Serratula tinctoria attained from 7.2 to 24.5 in the largest gaps, from 3.6 to 18.7 in the medium openings and from 2.6 to 7.4 in the smallest ones. The mean number of descendants of Gladiolus imbricatus achieved from 4.4 to 7.4 in the greatest gaps, from 2.0 to 5.0 in the medium openings and from 1.8 to 3.5 in the smallest ones. The statistical significance of differences in abun- dance of seedlings noted within successive subplots is given in Table 10.

\section{DISCUSSION}

\subsection{The impact of neighbouring plant height on seedling abundance}

Performed investigations document significant diminishing of recruitment rates of

Table 2. The statistical variability of number of seedlings of Gentiana pneumonanthe, Dianthus superbus, Serratula tinctoria and Gladiolus imbricatus recruited during whole study period in experimental plots within patches of Molinietum caeruleae dominated by low meadow species (MC), large-tussock grasses (GR) and willows (SA) in Area A and Area B. Asterisks mean that the mean number of seedlings differed significantly at $P \leq 0.05\left(^{*}\right), P<0.01\left(^{* *}\right), P<0.001\left(^{* * *}\right)$; ns-not significant differences (H KruskalWallis test).

\begin{tabular}{|c|c|c|c|c|}
\hline \multirow{8}{*}{ 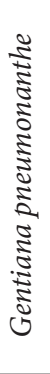 } & \multirow{4}{*}{ Area A } & \multirow{4}{*}{$\begin{array}{c}\text { The value of Kruskal-Wallis test } \\
\text { The level of statistical significance of differences } \\
\text { among sites: }\end{array}$} & \multicolumn{2}{|c|}{$4.65^{\mathrm{ns}}$} \\
\hline & & & MC and GR & ns \\
\hline & & & $\mathrm{MC}$ and $\mathrm{SA}$ & ns \\
\hline & & & GR and $S A$ & ns \\
\hline & \multirow{4}{*}{ Area B } & The value of Kruskal-Wallis test & & \\
\hline & & \multirow{3}{*}{$\begin{array}{l}\text { The level of statistical significance of differences } \\
\text { among sites: }\end{array}$} & MC and GR & ns \\
\hline & & & MC and SA & $P \leq 0.05$ \\
\hline & & & GR and SA & ns \\
\hline \multirow{8}{*}{ 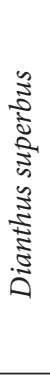 } & \multirow{4}{*}{ Area A } & The value of Kruskal-Wallis test & & \\
\hline & & \multirow{3}{*}{$\begin{array}{c}\text { The level of statistical significance of differences } \\
\text { among sites: }\end{array}$} & MC and GR & ns \\
\hline & & & $\mathrm{MC}$ and $\mathrm{SA}$ & ns \\
\hline & & & GR and SA & ns \\
\hline & \multirow{4}{*}{ Area B } & The value of Kruskal-Wallis test & 23 & \\
\hline & & \multirow{3}{*}{$\begin{array}{l}\text { The level of statistical significance of differences } \\
\text { among sites: }\end{array}$} & MC and GR & $P \leq 0.05$ \\
\hline & & & $\mathrm{MC}$ and $\mathrm{SA}$ & $P<0.001$ \\
\hline & & & GR and SA & ns \\
\hline \multirow{8}{*}{ 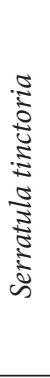 } & \multirow{4}{*}{ Area A } & The value of Kruskal-Wallis test & & \\
\hline & & \multirow{3}{*}{$\begin{array}{c}\text { The level of statistical significance of differences } \\
\text { among sites: }\end{array}$} & MC and GR & ns \\
\hline & & & $\mathrm{MC}$ and SA & ns \\
\hline & & & GR and SA & ns \\
\hline & \multirow{4}{*}{ Area B } & The value of Kruskal-Wallis test & 22 & \\
\hline & & \multirow{3}{*}{$\begin{array}{c}\text { The level of statistical significance of differences } \\
\text { among sites: }\end{array}$} & MC and GR & $P \leq 0.05$ \\
\hline & & & $\mathrm{MC}$ and $\mathrm{SA}$ & $P<0.001$ \\
\hline & & & GR and $S A$ & ns \\
\hline \multirow{8}{*}{ 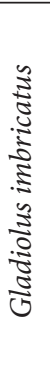 } & \multirow{4}{*}{ Area A } & The value of Kruskal-Wallis test & & \\
\hline & & \multirow{3}{*}{$\begin{array}{c}\text { The level of statistical significance of differences } \\
\text { among sites: }\end{array}$} & MC and GR & ns \\
\hline & & & $\mathrm{MC}$ and $\mathrm{SA}$ & $P \leq 0.05$ \\
\hline & & & GR and $S A$ & ns \\
\hline & \multirow{4}{*}{ Area B } & The value of Kruskal-Wallis test & & \\
\hline & & \multirow{3}{*}{$\begin{array}{c}\text { The level of statistical significance of differences } \\
\text { among sites: }\end{array}$} & MC and GR & ns \\
\hline & & & MC and SA & $P<0.001$ \\
\hline & & & GR and SA & ns \\
\hline
\end{tabular}


both, small- and large-seeded species along the gradient of growing shading. These results correspond well with previous observations (Kostrakiewicz 2010, 2011, Kostrakiewicz-Gierałt 2012,2013), which showed greater recruitment of seedlings of various taxa in patches of Molinietum caeruleae dominated by small meadow species, than in plots prevailed by large-tussock grasses and willows. In contrary, the laboratory experiments (Grime and Jeffrey 1965, Leishman and Westoby 1994, Milberg et al. 2000, Pearson et al. 2002, Jankowska-Błaszczuk and Daws 2007), as well as the observations carried out under semi-field conditions ( $\mathrm{Wu}$ et al. 2013) demonstrated that high light requirements for germination more likely characterize small- than in large-seeded taxa. Also, numerous field data have demonstrated an increase of large-seeded taxa recruitment along the gradient of rising shading. L ön $n$ berg and Eriksson (2012) observed the weak positive correlation between seed size and recruitment success from grasslands to forests. Bruun and ten Brink (2008) have showed, that the number of seedlings of large-seeded species increases, while the abundance of offsprings of small seeded taxa diminishes from open to closed habitats. Furthermore, the augmentation of positive relationship between seed size and seedling number along the gradient diminishing of light availability was documented in intra-specific studies (Lönnberg and Eriksson 2013).

\subsection{The influence of disturbance level on appearance of genets}

The obtained results, showing lack of 'recruits' in control subplots and the slight occurrence of 'recruits' in places without dead parts of plants suggest the negative effect of litter on seedling recruitment irrespective of seed mass. The unfavourable effect of necromass on seedling establishment, which has been observed previously in several productive

Table 3. The number of seedlings of small-seeded taxa Gentiana pneumonanthe and Dianthus superbus in subplots with no disturbance (1), low disturbance level (2), medium disturbance level (3) and high disturbance level (4) within patches of Molinietum caeruleae dominated by low meadow species (MC), large-tussock grasses (GR) and willows (SA) in the years 2007-2010.

\begin{tabular}{|c|c|c|c|}
\hline Species & Patch & Subplot & The average number of seedlings $( \pm S D)$ \\
\hline \multirow{12}{*}{ Gentiana pneumonanthe } & \multirow{4}{*}{$\mathrm{MC}$} & 1 & 0 \\
\hline & & 2 & $0.3(0.4)$ \\
\hline & & 3 & $5.9(3.3)$ \\
\hline & & 4 & $4.9(4.0)$ \\
\hline & \multirow{4}{*}{ GR } & 1 & 0 \\
\hline & & 2 & $2.3(1.8)$ \\
\hline & & 3 & $3.0(2.4)$ \\
\hline & & 4 & $7.5(5.0)$ \\
\hline & \multirow{4}{*}{ SA } & 1 & 0 \\
\hline & & 2 & $1.2(0.9)$ \\
\hline & & 3 & $3.1(1.7)$ \\
\hline & & 4 & $2.4(3.2)$ \\
\hline \multirow{12}{*}{ Dianthus superbus } & \multirow{4}{*}{$\mathrm{MC}$} & 1 & 0 \\
\hline & & 2 & $1.1(2.3)$ \\
\hline & & 3 & $5.4(3.9)$ \\
\hline & & 4 & $5.0(2.9)$ \\
\hline & \multirow{4}{*}{ GR } & 1 & 0 \\
\hline & & 2 & $2.8(3.2)$ \\
\hline & & 3 & $3.8(3.5)$ \\
\hline & & 4 & $3.1(2.0)$ \\
\hline & \multirow{4}{*}{ SA } & 1 & 0 \\
\hline & & 2 & $0.2(0.4)$ \\
\hline & & 3 & $4.8(2.8)$ \\
\hline & & 4 & $1.2(1.6)$ \\
\hline
\end{tabular}


Table 4. The statistical variability of number of seedlings of Gentiana pneumonanthe and Dianthus superbus in subplots with no disturbance (1), low disturbance level (2), medium disturbance level (3) and high disturbance level (4) within patches of Molinietum caeruleae dominated by low meadow species (MC), large-tussock grasses (GR) and willows (SA) in the years 2007-2010. Asterisks mean the probability that mean number of seedlings among subplots differed significantly at $P \leq 0.05\left(^{*}\right), P<0.01\left(^{* *}\right)$, $\left.P<0.001{ }^{(* *}\right)$; ns-not significant differences (H Kruskal-Wallis test).

\begin{tabular}{|c|c|c|c|c|}
\hline \multirow{21}{*}{ 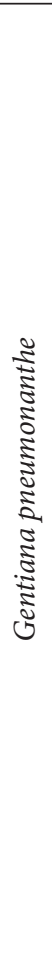 } & \multirow{7}{*}{$\mathrm{MC}$} & The value of Kruskal-Wallis test & \multicolumn{2}{|c|}{$26.52^{* * *}$} \\
\hline & & \multirow{6}{*}{$\begin{array}{l}\text { The level of statistical significance of differences } \\
\text { among subplots }\end{array}$} & 1 and 2 & ns \\
\hline & & & 1 and 3 & $P<0.001$ \\
\hline & & & 1 and 4 & $P<0.01$ \\
\hline & & & 2 and 3 & $P \leq 0.05$ \\
\hline & & & 2 and 4 & ns \\
\hline & & & 3 and 4 & ns \\
\hline & & The value of Kruskal-Wallis test & & \\
\hline & & & 1 and 2 & ns \\
\hline & & & 1 and 3 & $P<0.01$ \\
\hline & GR & The level of statistical significance of differences & 1 and 4 & ns \\
\hline & & among subplots & 2 and 3 & ns \\
\hline & & & 2 and 4 & ns \\
\hline & & & 3 and 4 & ns \\
\hline & & The value of Kruskal-Wallis test & & \\
\hline & & & 1 and 2 & ns \\
\hline & & & 1 and 3 & $P<0.01$ \\
\hline & SA & The level of statistical significance of differences & 1 and 4 & ns \\
\hline & & among subplots & 2 and 3 & ns \\
\hline & & & 2 and 4 & ns \\
\hline & & & 3 and 4 & ns \\
\hline \multirow{21}{*}{ 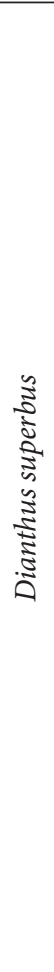 } & \multirow{7}{*}{$\mathrm{MC}$} & The value of Kruskal-Wallis test & \multicolumn{2}{|c|}{$21.57^{\star *}$} \\
\hline & & & 1 and 2 & ns \\
\hline & & & 1 and 3 & $P \leq 0.05$ \\
\hline & & The level of statistical significance of differences & 1 and 4 & $P \leq 0.05$ \\
\hline & & among subplots & 2 and 3 & ns \\
\hline & & & 2 and 4 & ns \\
\hline & & & 3 and 4 & ns \\
\hline & \multirow{7}{*}{ GR } & The value of Kruskal-Wallis test & \multicolumn{2}{|c|}{$12.10^{*}$} \\
\hline & & \multirow{6}{*}{$\begin{array}{l}\text { The level of statistical significance of differences } \\
\text { among subplots }\end{array}$} & 1 and 2 & ns \\
\hline & & & 1 and 3 & $P \leq 0.05$ \\
\hline & & & 1 and 4 & $P \leq 0.05$ \\
\hline & & & 2 and 3 & ns \\
\hline & & & 2 and 4 & ns \\
\hline & & & 3 and 4 & ns \\
\hline & \multirow{7}{*}{ SA } & The value of Kruskal-Wallis test & & \\
\hline & & \multirow{6}{*}{$\begin{array}{l}\text { The level of statistical significance of differences } \\
\text { among subplots }\end{array}$} & 1 and 2 & ns \\
\hline & & & 1 and 3 & $P<0.001$ \\
\hline & & & 1 and 4 & ns \\
\hline & & & 2 and 3 & $P<0.01$ \\
\hline & & & 2 and 4 & ns \\
\hline & & & 3 and 4 & ns \\
\hline
\end{tabular}


Table 5. The number of seedlings of large-seeded Serratula tinctoria and Gladiolus imbricatus in subplots with no disturbance (1), low disturbance level (2), medium disturbance level (3) and high disturbance level (4) within patches of Molinietum caeruleae dominated by low meadow species (MC), large-tussock grasses (GR) and willows (SA) in the years 2007-2010.

\begin{tabular}{|c|c|c|c|}
\hline Species & Patch & Subplot & The average number of seedlings $( \pm \mathrm{SD})$ \\
\hline \multirow{12}{*}{ Serratula tinctoria } & \multirow{4}{*}{ MC } & 1 & 0 \\
\hline & & 2 & $1.0(0.8)$ \\
\hline & & 3 & $18.2(6.4)$ \\
\hline & & 4 & $6.4(4.7)$ \\
\hline & \multirow{4}{*}{ GR } & 1 & 0 \\
\hline & & 2 & $0.8(1.3)$ \\
\hline & & 3 & $16.6(10.3)$ \\
\hline & & 4 & $3.6(2.7)$ \\
\hline & \multirow{4}{*}{ SA } & 1 & 0 \\
\hline & & 2 & $3.8(4.6)$ \\
\hline & & 3 & $11.8(8.8)$ \\
\hline & & 4 & $2.5(1.8)$ \\
\hline \multirow{12}{*}{ Gladiolus imbricatus } & \multirow{4}{*}{$\mathrm{MC}$} & 1 & 0 \\
\hline & & 2 & $1.2(1.3)$ \\
\hline & & 3 & $7.4(1.9)$ \\
\hline & & 4 & $2.6(1.9)$ \\
\hline & \multirow{4}{*}{ GR } & 1 & 0 \\
\hline & & 2 & $1.0(0.6)$ \\
\hline & & 3 & $4.2(2.7)$ \\
\hline & & 4 & $3.9(2.6)$ \\
\hline & \multirow{4}{*}{ SA } & 1 & 0 \\
\hline & & 2 & $1.2(2.4)$ \\
\hline & & 3 & $4.0(2.9)$ \\
\hline & & 4 & $3.4(4.6)$ \\
\hline
\end{tabular}

riparian plant communities (Xiong and Nilsson 1997, 1999, Xiong et al. 2003) and grasslands (Loydi et al. 2013) might be caused by diminishing of amplitude of temperature, reduction of the quality and amount of light reaching to the soil surface, isolation of seeds from available resources, attraction of predators, releasing allelochemicals, as well as fostering pathogens.

The sharp increase of seedling abundance of all studied species in effect of litter, moss and plant cover removal, might be linked with an enlargement of microhabitat suitable for seedling recruitment. In particular, the attention is drawn to the substantial number of offsprings of Serratula tinctoria, which might be connected with proximity of generative stems and dispersal of diaspores in short distances by wind or water (Bischoff 2002). Moreover, the chances for an increase of recruitment success might be caused by the dispersal of group of seeds connected by pappus.
Furthermore, it should be added that a rise of seedling abundance in effect of moderate disruption showed also other meadow taxa such as Iris sibirica and Trollius europaeus (Kostrakiewicz-Gierałt 2012).

The observed augmentation of number of offsprings of all studied taxa support the sowing experiments of Stammel et al. (2006). The aforementioned authors showed that regardless of seed mass, greater recruitment of seedlings occurred in mowing sites, than in gaps without plants and litter, as well as in abandoned plots. On the other hand $\mathrm{Kah}$ men and Poshlod (2008b) argued, that mowing and grazing applied in semi-natural grasslands favor the germination of small seeds, whereas the patch abandonment contribute to the germination success of larger seeds.

Observed in presented studies diminishing number of offsprings of Gentiana pneumonanthe, Dianthus superbus, Serratula tinctoria 
Table 6. The statistical variability of number of seedlings of Serratula tinctoria and Gladiolus imbricatus in subplots with no disturbance (1), low disturbance level (2), medium disturbance level (3) and high disturbance level (4) within patches of Molinietum caeruleae dominated by low meadow species (MC), large-tussock grasses (GR) and willows (SA) in the years 2007-2010. Asterisks mean the probability that mean number of seedlings among subplots differed significantly at $P \leq 0.05\left(^{*}\right), P<0.01\left(^{* *}\right), P<0.001$ $\left({ }^{* * *}\right)$; ns-not significant differences (H Kruskal-Wallis test).

\begin{tabular}{|c|c|c|c|c|}
\hline \multirow{21}{*}{$\begin{array}{l}\text { Serratula } \\
\text { tinctoria }\end{array}$} & \multirow{7}{*}{$\mathrm{MC}$} & The value of Kruskal-Wallis test & \multicolumn{2}{|c|}{$32.15^{\star * *}$} \\
\hline & & \multirow{6}{*}{$\begin{array}{c}\text { The level of statistical significance of differences } \\
\text { among subplots }\end{array}$} & 1 and 2 & ns \\
\hline & & & 1 and 3 & $P<0.001$ \\
\hline & & & 1 and 4 & $P<0.01$ \\
\hline & & & 2 and 3 & $P<0.001$ \\
\hline & & & 2 and 4 & ns \\
\hline & & & 3 and 4 & ns \\
\hline & & The value of Kruskal-Wallis test & & \\
\hline & & & 1 and 2 & ns \\
\hline & & & 1 and 3 & $P<0.001$ \\
\hline & GR & The level of statistical significance of differences & 1 and 4 & $P \leq 0.05$ \\
\hline & & among subplots & 2 and 3 & $P<0.001$ \\
\hline & & & 2 and 4 & ns \\
\hline & & & 3 and 4 & ns \\
\hline & & The value of Kruskal-Wallis test & & \\
\hline & & & 1 and 2 & ns \\
\hline & & & 1 and 3 & $P<0.001$ \\
\hline & SA & The level of statistical significance of differences & 1 and 4 & ns \\
\hline & & among subplots & 2 and 3 & ns \\
\hline & & & 2 and 4 & ns \\
\hline & & & 3 and 4 & ns \\
\hline \multirow{21}{*}{$\begin{array}{l}\text { Gladiolus } \\
\text { imbricatus }\end{array}$} & \multirow{7}{*}{$\mathrm{MC}$} & The value of Kruskal-Wallis test & \multicolumn{2}{|c|}{$28.21^{\star * *}$} \\
\hline & & & 1 and 2 & ns \\
\hline & & & 1 and 3 & $P<0.01$ \\
\hline & & The level of statistical significance of differences & 1 and 4 & ns \\
\hline & & among subplots & 2 and 3 & $P<0.01$ \\
\hline & & & 2 and 4 & ns \\
\hline & & & 3 and 4 & ns \\
\hline & \multirow{7}{*}{ GR } & The value of Kruskal-Wallis test & \multicolumn{2}{|c|}{$21.44^{\star *}$} \\
\hline & & \multirow{6}{*}{$\begin{array}{c}\text { The level of statistical significance of differences } \\
\text { among subplots }\end{array}$} & 1 and 2 & ns \\
\hline & & & 1 and 3 & $P<0.01$ \\
\hline & & & 1 and 4 & $P<0.01$ \\
\hline & & & 2 and 3 & ns \\
\hline & & & 2 and 4 & ns \\
\hline & & & 3 and 4 & ns \\
\hline & \multirow{7}{*}{ SA } & The value of Kruskal-Wallis test & \multicolumn{2}{|c|}{$15.85^{*}$} \\
\hline & & \multirow{6}{*}{$\begin{array}{c}\text { The level of statistical significance of differences } \\
\text { among subplots }\end{array}$} & 1 and 2 & ns \\
\hline & & & 1 and 3 & $P<0.01$ \\
\hline & & & 1 and 4 & ns \\
\hline & & & 2 and 3 & ns \\
\hline & & & 2 and 4 & ns \\
\hline & & & 3 and 4 & ns \\
\hline
\end{tabular}


Table 7. The number of seedlings of small-seeded taxa Gentiana pneumonanthe and Dianthus superbus in subplots measured $0.16 \mathrm{~m}^{2}$ (I), $0.09 \mathrm{~m}^{2}$ (II), $0.04 \mathrm{~m}^{2}$ (III), and $0.01 \mathrm{~m}^{2}$ (IV) within patches of Molinietum caeruleae dominated by low meadow species (MC), large-tussock grasses (GR) and willows (SA) in the years 2007-2010.

\begin{tabular}{|c|c|c|c|}
\hline Species & Patch & Subplot & The average number of seedlings $( \pm \mathrm{SD})$ \\
\hline \multirow{12}{*}{ Gentiana pneumonanthe } & \multirow{4}{*}{$\mathrm{MC}$} & I & $6.3(2.2)$ \\
\hline & & II & $3.5(1.7)$ \\
\hline & & III & $2.0(2.1)$ \\
\hline & & IV & $1.4(0.9)$ \\
\hline & \multirow{4}{*}{ GR } & I & $3.7(1.6)$ \\
\hline & & II & $3.1(1.3)$ \\
\hline & & III & $1.5(1.3)$ \\
\hline & & IV & $1.1(1.3)$ \\
\hline & \multirow{4}{*}{ SA } & I & $2.6(1.1)$ \\
\hline & & II & $2.8(1.2)$ \\
\hline & & III & $1.5(1.3)$ \\
\hline & & IV & $1.1(1.3)$ \\
\hline \multirow{12}{*}{ Dianthus superbus } & \multirow{4}{*}{$\mathrm{MC}$} & I & $7.5(2.1)$ \\
\hline & & II & $5.3(2.3)$ \\
\hline & & III & $4.8(0.9)$ \\
\hline & & IV & $3.5(1.2)$ \\
\hline & \multirow{4}{*}{ GR } & I & $4.7(1.3)$ \\
\hline & & II & $4.0(2.0)$ \\
\hline & & III & $3.8(1.3)$ \\
\hline & & IV & $2.8(1.8)$ \\
\hline & \multirow{4}{*}{ SA } & I & $3.8(3.0)$ \\
\hline & & II & $2.6(1.1)$ \\
\hline & & III & $2.3(0.8)$ \\
\hline & & IV & $1.5(0.9)$ \\
\hline
\end{tabular}

and Gladiolus imbricatus in gaps originated in effect of soil stripping might suggests the impoverishment of seed bank reserves. On the other hand numerous authors (Thompson et al. 1993, 1994, Thompson 2000, Bakker et al. 1996, Bekker et al. 1998) argued, that light-seeded taxa might reach great soil depth maintaining germination ability, while species with large diaspores are less likely to be incorporated into the soil. Additionally it should be pointed out, that artificial introducing of diaspores into places with bare soil increases the recruitment of seedlings of Gentiana pneumonanthe (Křenová and Lepš 1996) and Dianthus superbus (Poshold and Biewer 2005). The positive role of sod cutting and diaspore sowing on emergence of generative offsprings of numerous meadow taxa was documented by Špačkova et al. (1998), Kotorová and Lepš (1999), whilst Hölzel and Otte (2003) considered this treatment as an extremely successful method of restoring wet meadows.

\subsection{The effect of gap size on emergence of generative progeny}

The observations presented above, bringing evidence that irrespective of habitat conditions the germination success of small- and large-seeded species is greater in wide gaps than in smaller ones, are consistent with observations of colonization of openings by seedlings of Iris sibirica and Trollius europaeus (Kostrakiewicz-Gierałt 2012). Also studies conducted in heatlands (Miles 1974) and forests (Denslow 1987, Bullock 2000, Sapkota and Odén 2009) documented, that the majority of species tend to perform better in larger openings. Such phenomenon might be connected with an increase of the area in which taxa can successfully establish 
Table 8. The statistical variability of number of seedlings of Gentiana pneumonanthe and Dianthus superbus in subplots measured $0.16 \mathrm{~m}^{2}$ (I), $0.09 \mathrm{~m}^{2}$ (II), $0.04 \mathrm{~m}^{2}$ (III), and $0.01 \mathrm{~m}^{2}$ (IV) within patches of Molinietum caeruleae dominated by low meadow species (MC), large-tussock grasses (GR) and willows (SA) in the years 2007-2010. Asterisks mean the probability that mean number of seedlings among subplots differed significantly at $P \leq 0.05\left(^{*}\right), P<0.01\left(^{* *}\right), P<0.001\left(^{* * *}\right)$; ns-not significant differences (H Kruskal-Wallis test).

\begin{tabular}{|c|c|c|c|c|}
\hline \multirow{21}{*}{ 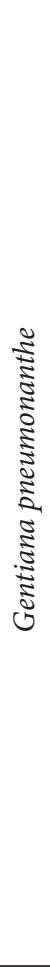 } & \multirow{7}{*}{$\mathrm{MC}$} & The value of Kruskal-Wallis test & \multicolumn{2}{|c|}{$15.36^{*}$} \\
\hline & & \multirow{6}{*}{$\begin{array}{c}\text { The level of statistical significance of differences } \\
\text { among subplots }\end{array}$} & I and II & ns \\
\hline & & & I and III & $P<0.01$ \\
\hline & & & I and IV & $P<0.01$ \\
\hline & & & II and III & ns \\
\hline & & & II and IV & ns \\
\hline & & & III and IV & ns \\
\hline & & The value of Kruskal-Wallis test & & \\
\hline & & & I and II & ns \\
\hline & & & I and III & ns \\
\hline & GR & The level of statistical significance of differences & I and IV & $P \leq 0.05$ \\
\hline & & among subplots & II and III & ns \\
\hline & & & II and IV & ns \\
\hline & & & III and IV & ns \\
\hline & & The value of Kruskal-Wallis test & & \\
\hline & & & I and II & ns \\
\hline & & & I and III & $P<0.01$ \\
\hline & SA & The level of statistical significance of differences & I and IV & ns \\
\hline & & among subplots & II and III & ns \\
\hline & & & II and IV & ns \\
\hline & & & III and IV & ns \\
\hline \multirow{21}{*}{ 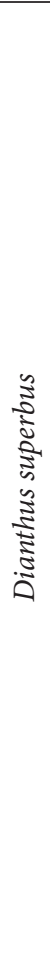 } & \multirow{7}{*}{$\mathrm{MC}$} & The value of Kruskal-Wallis test & & \\
\hline & & \multirow{6}{*}{$\begin{array}{l}\text { The level of statistical significance of differences } \\
\text { among subplots }\end{array}$} & I and II & ns \\
\hline & & & I and III & ns \\
\hline & & & I and IV & $P<0.001$ \\
\hline & & & II and III & ns \\
\hline & & & II and IV & ns \\
\hline & & & III and IV & ns \\
\hline & \multirow{7}{*}{ GR } & The value of Kruskal-Wallis test & & \\
\hline & & \multirow{6}{*}{$\begin{array}{l}\text { The level of statistical significance of differences } \\
\text { among subplots }\end{array}$} & I and II & ns \\
\hline & & & I and III & ns \\
\hline & & & I and IV & ns \\
\hline & & & II and III & ns \\
\hline & & & II and IV & ns \\
\hline & & & III and IV & ns \\
\hline & \multirow{7}{*}{ SA } & The value of Kruskal-Wallis test & & \\
\hline & & \multirow{6}{*}{$\begin{array}{l}\text { The level of statistical significance of differences } \\
\text { among subplots }\end{array}$} & I and II & ns \\
\hline & & & I and III & ns \\
\hline & & & I and IV & ns \\
\hline & & & II and III & ns \\
\hline & & & II and IV & ns \\
\hline & & & III and IV & ns \\
\hline
\end{tabular}


and grow, as well as with an augmentation of level of resources available for exploitation. They asserted, that the surface of the soil in a large opening generally receives higher light intensities, and thus the soil temperature is generally higher than that in small openings. In contrast, observations made in habitats as diverse as old fields (McConnaughay and Bazzaz 1987), grasslands (Burke and Grime 1996), meadows (Kostrakiewicz 2011), as well as forests (Foster and Jan son 1985, Alvarez-Buylla and MartinezRamos 1990, Seiwa and Kikuzawa 1996, Ellis on et al. 1993, van Ulft 2004) have brought evidence that the germination success of small-seeded species rises, while that of large-seeded species diminishes as the gap area increases. The above mentioned authors observed an increased risk of desiccation in wider gaps. Such phenomenon might be a far more important seed mortality agent for large than for smaller seeded species.

\section{CONCLUSIONS}

Concluding, it should be pointed out, that the gap creating might be an effective way for active protection of both: small- and large-seeded taxa. The role of gaps as microhabitats suitable for seedling recruitment diminishes gradually: from the patch dominated by low-stature meadow species, via the place prevailed by tall grasses, to the site overgrown by willows. Regardless of character of standing vegetation, the best results brings removal of above-ground parts of plants and litter layer. Such treatment allows the reduction of competition from neighbors and the preservation of soil seed bank reserves, simultaneously. Moreover, an increase of opening area contributes to significant augmentation of recruitment success of all studied species.

AKNOWLEDGMENTS: I wish to thank three anonymous reviewers for valuable comments on the manuscript.

Table 9. The number of seedlings of large-seeded taxa Serratula tinctoria and Gladiolus imbricatus in subplots measured $0.16 \mathrm{~m}^{2}$ (I), $0.09 \mathrm{~m}^{2}$ (II), $0.04 \mathrm{~m}^{2}$ (III), and $0.01 \mathrm{~m}^{2}$ (IV) within patches of Molinietum caeruleae dominated by low meadow species (MC), large-tussock grasses (GR) and willows (SA) in the years 2007-2010.

\begin{tabular}{|c|c|c|c|}
\hline Species & Patch & Subplot & The average number of seedlings $( \pm \mathrm{SD})$ \\
\hline \multirow{12}{*}{ Serratula tinctoria } & \multirow{4}{*}{$\mathrm{MC}$} & I & $24.5(14.4)$ \\
\hline & & II & $18.7(18.1)$ \\
\hline & & III & $8.3(2.6)$ \\
\hline & & IV & $7.4(3.3)$ \\
\hline & \multirow{4}{*}{ GR } & I & $12.4(5.1)$ \\
\hline & & II & $9.9(1.1)$ \\
\hline & & III & $5.8(4.1)$ \\
\hline & & IV & $3.7(3.1)$ \\
\hline & \multirow{4}{*}{ SA } & I & $7.2(2.6)$ \\
\hline & & II & $5.3(2.4)$ \\
\hline & & III & $3.6(2.9)$ \\
\hline & & IV & $2.6(2.5)$ \\
\hline \multirow{12}{*}{ Gladiolus imbricatus } & \multirow{4}{*}{ MC } & I & $7.4(3.5)$ \\
\hline & & II & $5.0(3.1)$ \\
\hline & & III & $4.0(2.0)$ \\
\hline & & IV & $3.5(1.4)$ \\
\hline & \multirow{4}{*}{ GR } & I & $6.2(2.2)$ \\
\hline & & II & $4.1(2.7)$ \\
\hline & & III & $2.8(1.3)$ \\
\hline & & IV & $2.6(0.9)$ \\
\hline & \multirow{4}{*}{ SA } & I & $4.4(1.5)$ \\
\hline & & II & $2.7(2.0)$ \\
\hline & & III & $2.0(0.9)$ \\
\hline & & IV & $1.8(0.7)$ \\
\hline
\end{tabular}


Table 10. The statistical variability of number of seedlings of Serratula tinctoria and Gladiolus imbricatus in subplots measured $0.16 \mathrm{~m}^{2}(\mathrm{I}), 0.09 \mathrm{~m}^{2}$ (II), $0.04 \mathrm{~m}^{2}$ (III), and $0.01 \mathrm{~m}^{2}$ (IV) within patches of Molinietum caeruleae dominated by low meadow species (MC), large-tussock grasses (GR) and willows (SA) in the years 2007-2010. Asterisks mean the probability that mean number of seedlings among subplots differed significantly at $P \leq 0.05\left(^{*}\right), P<0.01\left(^{* *}\right), P<0.001\left(^{* * *}\right)$; ns-not significant differences (H Kruskal-Wallis test).

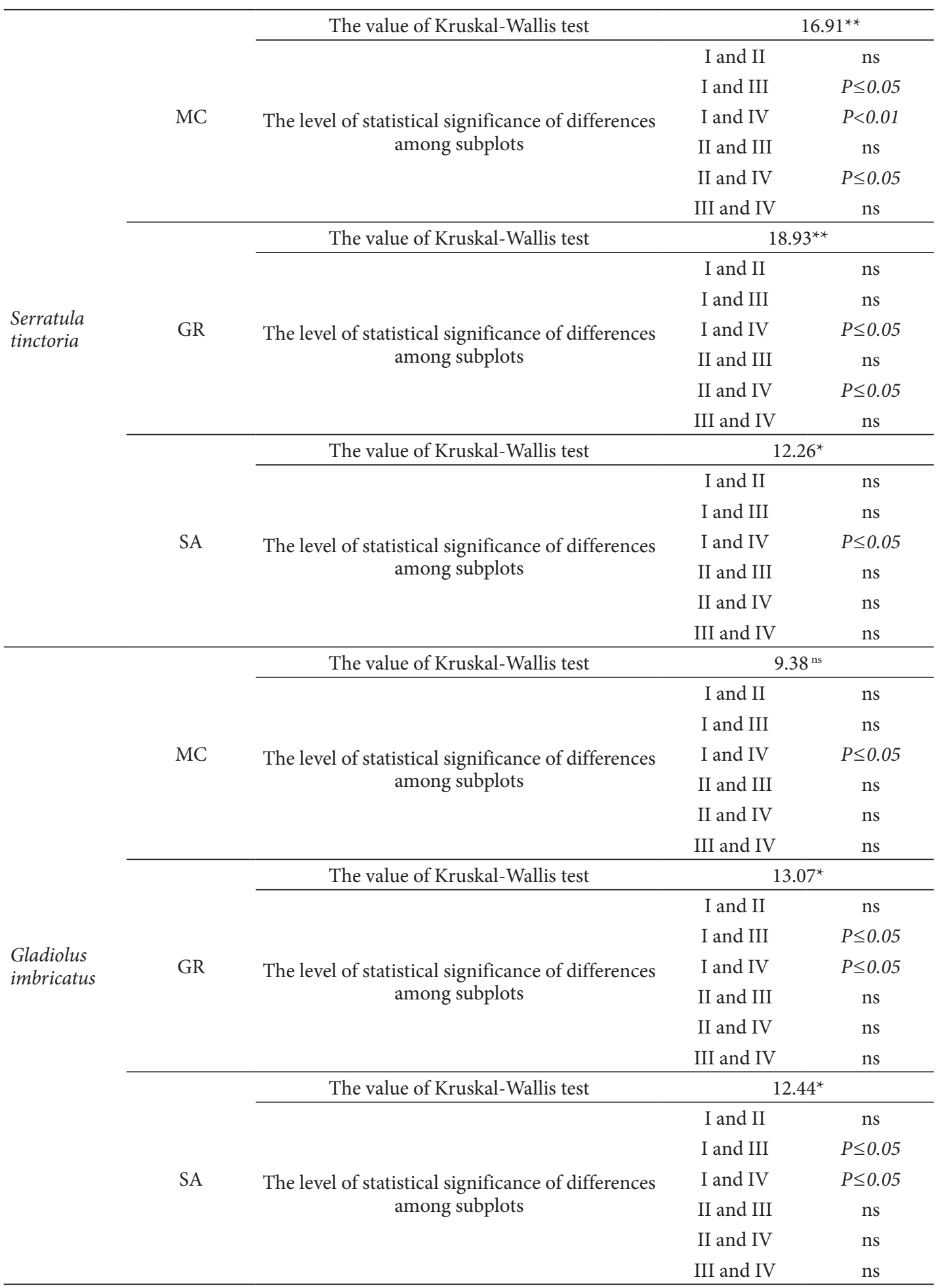




\section{REFERENCES}

Alvarez-Buylla E.R., Martinez-Ramos M. 1990 - Seed bank versus seed rain in the regeneration of a tropical pioneer tree - Oecologia, 84: 314-325.

Bakker J.P., Poschlod P., Strykstra R.J., Bekker R.M., Thompson K. 1996 - Seed banks and seed dispersal: Important topics in restoration ecology - Acta Bot. Neerl. 45: 461-490.

Bekker R.M., Bakker J.P., Grandin U., Kalamees R., Milberg P., Poschlod P. Thompson K., Willems J.H. 1998 - Seed size, shape and vertical distribution in the soil: indicators of seed longevity - Funct. Ecol. 12: 834-842.

Bischoff A. 2002 - Dispersal and establishment of floodplain grassland species as limiting factors in restoration - Biol. Conserv. 104: 25-33.

Bruun H.H., Ten Brink D-J. 2008 - Recruitment advantage of large seeds is greater in shaded habitats - Ecoscience, 15: 498-507.

Bu H., Chen X., Xu X., Liu K., Jia P., Du G. 2007 - Seed mass and germination in an alpine meadow on the eastern Tsinghai-Tibet plateau - Plant Ecol. 191: 127-149.

Bullock J.M. 2000 - Gaps and seedling colonization. (In: Seeds: The Ecology of Regeneration in Plant Communities, Ed: M. Fenner) - CABI Publishing, Wallingford, UK, pp. 375-95.

Burke M.J.W., Grime J.P. 1996 - An experimental study of plant community invasibility - Ecology, 77: 776-790.

Cerabolini B., Ceriani R.M., Caccianiga M., De Andreis R., Raimondi B. 2003 - Seed size, shape and persistence in soil: a test on Italian flora from Alps to Mediterranean coasts - Seed Sci. Res. 13: 75-85.

Cheffings Ch.M., Farrell L. 2005 - The Vascular Plant Red Data List for Great Britain. Species Status - Joint Nature Conservation Commitee Petrborough, 166 pp.

Colling G. 2005 - Red List of Vascular Plants of Luxembourg. Ferrantia. - Trav. Scientif. Mus. Hist. Nat. Lux. 42: 1-77.

Conti F., Manzi A., Pedrotti F. 1997 -Libro rosso regionali delle piante d'Italia - WWF, Assocazione Italiana per In World Wildlife Fund in collaborazione con la Societá Botanica Italiana, Camerino, $139 \mathrm{pp}$.

Curtis T.G.F., McGough H.N. 1988 - The Irish Red Data Book. 1 Vascular Plants - Wildlife Service Ireland, Dublin 169 pp.

Denslow J.S. 1987 - Tropical rainforest gaps and tree species diversity - Ann. Rev. Ecol. Syst. 18:431-451.
Dubiel E. 1991 - Map of actual vegetation of the city of Cracow - Zesz. Nauk. UJ. Prace Botaniczne, 22: 121-133.

Dubiel E. 1996 - Łąki Krakowa. I Klasa Molinio-Arrhenatherea - Studia Ośrodka Dokumentacji Fizjograficznej [Meadows in Cracow. Part I: Molinio-Arrhenatherea class], 24: 145-171.

Ellison A.M., Denslow J.S., Loiselle B.A., Brenés M.D. 1993 - Seed and seedling ecology of neotropical Melastomaceae - Ecology, 74: 1733-1749.

Eriksson A., Eriksson O. 1997 - Seedling recruitment in semi-natural pastures: the effects of disturbances, seed size, phenology and seed bank - Nordic J. Botany 17: 469-482.

Eriksson O., Jakobsson A. 1998 - Abundance, distribution and life histories of grassland plants: a comparative study of 81 species - J. Ecol. 86 922-933.

Foster S.A., Janson C.H. 1985 - The relationship between seed size and establishment conditions on tropical woody plants - Ecology, 66: 773-780.

Grime J.P., Jeffrey D.W. 1965 - Seedling establishment in vertical gradients of sunlight J. Ecol. 53: 621-642.

Holub J., Procházka F. 2000 - Red list of the flora of the Czech Republic (state in the year 2000) - Preslia Praha, 72: 187-230.

Hölzel N., Otte A. 2003 - Restoration of a species-rich flood meadow by topsoil removal and diaspore transfer with plant material Appl. Veg. Sci. 6: 131-144.

Ingelög T., Andersson R., Tjenberg M. 1993 - Red Data Book of The Baltic Region. Part 1 Lists of threatened vascular plants and vertebrates - Swedish Threatened Species Unit, Uppsala, Institute of Biology, Riga 95 pp.

Jakobsson A., Eriksson O. 2000 - A comparative study of seed number, seed size, seedling size and recruitment in grassland plants - Oikos, 88: 494-502.

Jankowska-Błaszczuk M., Daws M.I. 2007 - Impact of red: far red ratios on germination of temperate forest herbs in relation to shade tolerance, seed mass and persistence in the soil - Funct. Ecol. 21: 1055-1062.

Kahmen S., Poschlod P. 2008a-Does germination success differ with respect to seed mass and germination season? Experimental testing of plant functional trait responses to grassland management - Ann. Bot. 101: 541-548.

Kahmen S., Poschlod P. 2008b - Effects of grassland management on plant functional trait composition - Agr. Ecosys. Environ. 128: 137-145.

Kern Ch.C., Montgomery R.A., Peter B., Reich P.B., Strong T.F. 2013 - Canopy 
gap size influences niche partitioning of the ground-layer plant community in a northern temperate forest - J. Plant Ecol. 6: 101-112.

Korneck D., Schnittler M., Vollmer I. 1996 - Rote Liste der Farn- und Blütenpflanzen (Pteridophyta et Spermatophyta) Deutschlands (In: Rote Liste gefährdeter Pflanzen Deutschlands, Eds: G. Ludwig, M. Schnittler) - Schriftenreihe für Vegetationskunde 28, Bundesamt für Naturschutz, BonnBad Godesberg, pp. 21-187.

Kostrakiewicz K. 2010 - The effect of gaps on seedlings recruitment of threatened species in Molinietum caeruleae W.Koch 1926 Chrońmy Przyr. Ojcz. 66: 184-189 (in Polish, English summary).

Kostrakiewicz K. 2011 - The effect of gaps size on colonization process in Molinietum caeruleae meadows with different habitat conditions - Pol. J. Ecol. 59: 677-686.

Kostrakiewicz-Gierałt K. 2012 - The impact of neighbourhood and gap character on seedling recruitment of Trollius europaeus L. and Iris sibirica L. in Molinietum caeruleae meadows - Biodiv. Res. Conserv. 28: 37-44.

Kostrakiewicz-Gierałt K. 2013 - The impact of disturbance severity on recruitment of clonal plant species in Molinietum caeruleae meadows - Pol. J. Ecol. 61: 519-533.

Kotiranta H., Uotila P., Sulkava S., Peltonen S.L. 1998 - Red Data Book of East Fennoscandia - Ministry of the Environment, Finnish Environment Institute \& Botanical Museum, Finnish Museum of Natural History, Helsinki, 351 pp.

Kotorová I, Lepš J. 1999 - Comparative ecology of seedling recruitment in an oligotrophic wet meadow - J. Veg. Sci. 10: 175-186.

Křenová Z., Lepš J. 1996 - Regeneration of a Gentiana pneumonanthe population in an oligotrophic wet meadow - J. Veg. Sci. 7: 107112.

Kubikova P., Zeidler M. 2011 - Habitat demands and population characteristics of the rare plant species Gladiolus imbricatus L. in the Frenštát region (NE Moravia, the Czech Republik) - Čas. Slez. Muz. Opava, 60: 154164.

Leishman M.R. 2001 - Does the seed size/ number trade-off model determine plant community structure? An assessment of the model mechanisms and their generality - Oikos, 93: 294-302.

Leishman M.R., Westoby M. 1994 - The role of large seed size in shaded conditions: experimental evidence - Funt. Ecol. 8: 205-214.

Loydi A., Eckstein R.L., Otte A., Donath T.W. 2013 - Effects of litter on seedling es- tablishment in natural and semi-natural grasslands: A meta-analysis - J. Ecol. 101: 454-464.

Lönnberg K., Eriksson K. 2012 - Seed size and recruitment patterns in a gradient from grassland to forest - Ecoscience, 19: 140-147.

Lönnberg K., Eriksson O. 2013 - Relationships between intra-specific variation in seed size and recruitment in four species in two contrasting habitats - Plant. Biol. 15: 601-606.

Matuszkiewicz W. 2012 - Przewodnik do oznaczania zbiorowisk roślinnych Polski [A guide to plant communities of Poland] - PWN Warszawa, 540 pp. (in Polish).

McConnaughay K.D.M., Bazzaz F.A. 1987 - The relationship between gap size and performance of several colonizing annuals - Ecology, 68: 411-416.

Meusel H., Jäger E., Weinert E. 1965 Vergleichende Chorologie der Zentraleuropäischen Flora. Bd.I - Gustav Fisher, Jena, 583 pp, karten 258.

Milberg P., Andersson L., Thompson K. 2000 - Large-seeded species are less dependent on light for germination than small-seeded ones - Seed Sci. Res. 10: 99-104.

Miles J. 1974 - Effects of experimental interference with stand structure on establishment of seedlings in Callunetum - J. Ecol. 62: 657-687.

Moles A., Westoby M. 2004 - Seedling survival and seed size: a synthesis of the literature - J. Ecol. 92: 372-383.

Moles A., Westoby M. 2006 - Seed size and plant strategy across the whole life cycle Oikos, 113: 91-105.

Moser D.M., Gygax A., Bäumler B., Wyler N., Palese R. 2002 - Rote Liste der gefährdeten Farn- und Blütenpflanzen der Schweiz-Hrsg. Bundesamt für Umwelt, Wald und Landschaft, Bern, Zentrum des Datenverbundnetzes der Schweizer Flora, Chambésy, Conservatoire et Jardin botaniques de la Ville de Genève, Chambésy - BUWAL-Reihe „Vollzug Umwelt", 118 pp.

Niklfeld H., Schratt-Ehrendorfer L. 1999 - Rote Liste gefährdeter Farn- und Blütenpflanzen (Pteridophyta and Spermatophyta) Österreichs. 2 Fassung, (In: Rote Listen Gefährdeter Pflanzen Grüne Österreichs, Ed: H. Niklfeld) - Bundesministerium für Umwelt, Jugend und Familie, Vien, pp. 33-151.

Pearson T.R.H., Burslem D.F.R.P., Mullins C.E., Dalling J.W. 2002 - Germination ecology of neotropical pioneers: interacting effects of environmental conditions and seed size - Ecology, 83: 2798-2807.

Poshold P., Biewer H. 2005 - Diaspore and gap availability are limiting species richness in wet meadows - Folia Geobot. 40: 13-34. 
Procházka F. 2001 - Černý a červený seznam cévnatých rostlin České republiky (stav v roce 2000). - Pŕíroda Praha, 18: 1-166.

Reader R.J. 1993 - Control of seedling emergence by ground cover and seed predation in relation to seed size for some old-field species - J. Ecol. 81: 169-175.

Ryser P. 1993 - Influences of neighbouring plants on seedling establishment in limestone grassland - J. Veg. Sci. 4: 195-202.

Sapkota I.P., Odén P.Ch. 2009 - Gap characteristics and their effects on regeneration, dominance and early growth of woody species - J. Plant Ecol. 2: 21-29.

Seiwa K., Kikuzawa K. 1996 - Importance of seed size for the establishment of seedlings of five deciduous broad-leaved tree species Vegetatio, 123: 51-64.

Simmonds N.W. 1946 - Biological flora of the British Isles, Gentiana pneumonanthe L. - J. Ecol. 33: 295-307.

Špačkova I, Kotorová I., Lepš J. 1998 Sensivity of seedling recruitment to moss, litter and dominant removal in an oligotrophic wet meadow - Folia Geobot. 33: 17-30.

Stammel B., Kiehl K., Pfadenhauer J. 2006 - Effects of experimental and real land use on seedling recruitment of six fen species - Basic Appl. Ecol. 7: 334-346.

Thompson K. 2000 - The functional ecology of soil seed banks (In: Seeds- the Ecology of Regeneration in Plant Communities, Ed: M. Fenner) CABI Publishing, Wallingford, UK, pp. 215-36.

Thompson K., Band S. R., Hodgson J. G. 1993 - Seed size and shape predict persistence in the soil - Funct. Ecol. 7: 236-241.

Thompson K., Green A., Jewels A. M. 1994 - Seeds in soil and worm casts from a neutral grassland - Funct. Ecol. 8: 29-35.
Turnbull L.A., Coomes D., Hector A., Rees M. 2004 - Seed mass and the competition/colonization trade-off: competitive interactions and spatial patterns in a guild of annual plants - J. Ecol. 92: 97-109.

van Ulft L.H. 2004 - The effect of seed mass and gap size on seed fate of tropical rain forest tree species in Guyana - Plant Biology, 6: 214-221.

Wu G.L., Du G.Z., Shi Z.H. 2013 - Germination strategies of 20 alpine species with varying seed mass and light availability - Aust. J. Bot. 61: 404-411.

Xiong S, Nilsson C. 1997 - Dynamics of leaf litter accumulation and it effects on riparian vegetation: A review - Bot. Rev. 63: 240-264.

Xiong S., Nilsson C. 1999 - The effects of plant litter on vegetation: a meta-analysis - J. Ecol. 87: 984-994.

Xiong S.J., Johansson M.E., Hughes F.M.R., Hayes A., Richards K.S., Nilsson C. 2003 -Interactive effects of soil moisture, vegetation canopy, plant litter and seed addition on plant diversity in a wetland community - J. Ecol. 91: 976-986.

Zarzycki K., Szaląg Z. 2006 - Red List of The Vascular Plants in Poland (In: Red List of Plants and Fungi in Poland, Eds: Z. Mirek, W. Zarzycki, Z. Wojewoda, Z. Szeląg) - Polish Academy of Sciences, W. Szafer Institute of Botany, Krakow, pp. 9-21.

Zoltan R. (Szerkeztette), Bankovics A., Györyj J., Kaszab Z., Nechay G., Nemeth F., Papp J., Rajczy M., Rakonczay Z., Sterbetz I., Trmedi I., Varga Z. 1990 - Vörös könyv. A. magyarországon kipusztult ésveszélyeztetett növény-és állatfajok - Akadémiai Kiadó, Budapest, 360 pp. 


\section{APPENDIX I}

The categories of threat of studied species in Eastern and Central Europe. Numbers refer to Red Lists/Books cited in alphabetical order:

\begin{tabular}{|c|c|c|c|c|c|c|}
\hline \multirow[b]{2}{*}{ Species } & \multicolumn{6}{|c|}{ The IUCN categories } \\
\hline & $\begin{array}{l}\text { Extinct } \\
\text { (EX) }\end{array}$ & $\begin{array}{l}\text { Critically } \\
\text { endangered } \\
\text { (CE) }\end{array}$ & $\begin{array}{l}\text { Endangered } \\
\qquad(\mathrm{EN})\end{array}$ & $\begin{array}{l}\text { Vulnerable } \\
\text { (VU) }\end{array}$ & $\begin{array}{l}\text { Near threat- } \\
\text { ened (NT) }\end{array}$ & $\begin{array}{l}\text { Least concern } \\
\text { (LC) }\end{array}$ \\
\hline $\begin{array}{l}\text { Gentiana } \\
\text { pneumo- } \\
\text { nanthe }\end{array}$ & $\begin{array}{c}\text { Kaliningrad } \\
\text { Region }^{8}\end{array}$ & & $\begin{array}{c}\text { Czech } \\
\text { Republik }^{5,11}\end{array}$ & $\begin{array}{l}\text { Switzerland }^{9} \\
\text { Poland }^{12} \\
\text { Lithuania }^{6} \\
\text { Latvia }^{6} \\
\text { Meclenburg }^{\text {state }} \\
\text { schleswig }^{6} \\
\text {-Holstein } \\
\text { state }^{6}\end{array}$ & Hungary ${ }^{13}$ & Great Britain $^{1}$ \\
\hline $\begin{array}{l}\text { Dianthus } \\
\text { superbus }\end{array}$ & & $\begin{array}{c}\text { Czech } \\
\text { Republik }^{5,11}\end{array}$ & $\begin{array}{c}\text { Lithuania }^{6} \\
\text { Latvia }^{6} \\
\text { Schleswig- } \\
\text { Holstein } \\
\text { state }^{6} \text { Austria }\end{array}$ & $\begin{array}{l}\text { Leningrad } \\
\text { Region }^{8} \\
\text { Poland }^{12} \\
\text { Germany }^{7}\end{array}$ & Hungary $^{13}$ & Switzerland $^{9}$ \\
\hline $\begin{array}{l}\text { Serratula } \\
\text { tinctoria }\end{array}$ & Ireland ${ }^{4}$ & Luxembourg $^{2}$ & Italy $^{2}$ & & & Great Britain ${ }^{1}$ \\
\hline $\begin{array}{l}\text { Gladiolus } \\
\text { imbricatus }\end{array}$ & & $\begin{array}{c}\text { Czech } \\
\text { Republik }^{5,11}\end{array}$ & $\begin{array}{l}\text { Hungary }^{13} \\
\text { Switzerland }^{9} \\
\text { Poland }^{12} \\
\text { Kaliningrad } \\
\text { Region }^{8}\end{array}$ & $\begin{array}{c}\text { Lithuania }^{6} \\
\text { Leningrad } \\
\text { Region }^{6}\end{array}$ & & \\
\hline
\end{tabular}

${ }^{1}$ Cheffings and Farrell 2005; ${ }^{2}$ Colling 2005; 3Conti et al 1997; 4Curtis and McGough 1988; ${ }^{5} \mathrm{Holub}$ and Procházka 2000; ${ }^{6}$ Ingelög et al. $1993 ;{ }^{7}$ Korneck et al. $1998 ;{ }^{8}$ Kotiranta et al. $1998 ;{ }^{9}$ Moser et al. $2002 ;{ }^{10} \mathrm{Nikl}$ feld and Schratt-Ehrendorfer 1999; ${ }^{11}$ Procházka 2001; ${ }^{12}$ Zarzycki and Szeląg 2006; ${ }^{13}$ Zoltan et al. 1990. 


\section{APPENDIX II}

The characteristic of the habitat conditions in patches of Molinietum caeruleae dominated by low meadow species (MC), large-tussock grasses (GR) and willows (SA) in Area A and Area B.

\begin{tabular}{|c|c|c|c|c|c|c|}
\hline Area & Patch & Coordinates & $\begin{array}{l}\text { Patch size } \\
\qquad\left(\mathrm{m}^{2}\right)\end{array}$ & Dominants & $\begin{array}{l}\text { Maximal } \\
\text { height of } \\
\text { plant canopy } \\
(\mathrm{cm})\end{array}$ & $\begin{array}{l}\text { Mean height } \\
\text { of plant } \\
\text { canopy }(\mathrm{cm})\end{array}$ \\
\hline \multirow{3}{*}{ A } & $\mathrm{MC}$ & $\begin{array}{l}50^{\circ} 01^{\prime} 55.76^{\prime \prime} \mathrm{N} \\
19^{\circ} 52^{\prime} 03.06^{\prime \prime} \mathrm{E}\end{array}$ & 1400 & $\begin{array}{l}\text { Lathyrus pratensis, } \\
\text { Lychnis flos-cuculi, } \\
\text { Succisa pratensis }\end{array}$ & 159 & 96 \\
\hline & GR & $\begin{array}{c}50^{\circ} 01^{\prime} 55.23^{\prime \prime} \mathrm{N} \\
19^{\circ} 52^{\prime} 05.48^{\prime \prime} \mathrm{E}\end{array}$ & 1300 & $\begin{array}{c}\text { Molinia caerulea, } \\
\text { Deschampsia caespitosa, }\end{array}$ & 195 & 155 \\
\hline & SA & $\begin{array}{l}50^{\circ} 01^{\prime} 55.60^{\prime \prime} \mathrm{N} \\
19^{\circ} 52^{\prime} 04.45^{\prime \prime} \mathrm{E}\end{array}$ & 1450 & $\begin{array}{l}\text { Salix repens ssp. } \\
\text { rosmarinifolia, } \\
\text { S. cinerea } \\
\end{array}$ & 228 & 185 \\
\hline \multirow{3}{*}{ B } & $\mathrm{MC}$ & $\begin{array}{l}50^{\circ} 01^{\prime} 50.4^{\prime \prime} \mathrm{N} \\
19^{\circ} 52^{\prime} 03.2^{\prime \prime} \mathrm{E}\end{array}$ & 1600 & $\begin{array}{l}\text { Lotus corniculatus, } \\
\text { Briza media, } \\
\text { Lychnis flos-cuculi }\end{array}$ & 157 & 120 \\
\hline & GR & $\begin{array}{l}50^{\circ} 01^{\prime} 52.5^{\prime \prime} \mathrm{N} \\
19^{\circ} 52^{\prime} 03.0^{\prime \prime} \mathrm{E}\end{array}$ & 1200 & $\begin{array}{c}\text { Molinia caerulea, } \\
\text { Deschampsia caespitosa }\end{array}$ & 210 & 170 \\
\hline & SA & $\begin{array}{l}50^{\circ} 01^{\prime} 50.9^{\prime \prime} \mathrm{N} \\
19^{\circ} 52^{\prime} 02.9^{\prime \prime} \mathrm{E}\end{array}$ & 1500 & $\begin{array}{l}\text { Salix repens ssp. } \\
\text { rosmarinifolia, } \\
\text { S. cinerea, } \\
\text { S. aurita }\end{array}$ & 247 & 180 \\
\hline
\end{tabular}

